\title{
GENETIC MAPPING OF PEA (Pisum sativum L.) GENES INVOLVED IN SYMBIOSIS
}

\author{
(review)
}

\section{V.A. ZHUKOV1, O.Yu. SHTARK'1, T.A. NEMANKIN1, 2, A.A. KRYUKOV1, A.Yu. BORISOV 1 , I.A. TIKHONOVICH'1, 3}

\author{
${ }^{1}$ All-Russia Research Institute for Agricultural Microbiology, Federal Agency of Scientific Organizations, 3, sh. Pod- \\ bel'skogo, St. Petersburg, 196608 Russia, e-mail zhukoff01@yahoo.com; \\ ${ }^{2}$ Bio Cad Joint Stock Co., 34-A, ul. Svyazi, pos. Strelna, St. Petersburg, 198515 Russia; \\ ${ }^{3}$ Saint Petersburg State University, 7/9, Universitetskaya nab., St. Petersburg, 199034 Russia \\ (ORCID: Zhukov V.A. orcid.org/0000-0002-2411-9191, Borisov A.Y. orcid.org/0000-0001-9834-7368, Tikhono- \\ vich I.A. orcid.org/0000-0001-8968-854X) \\ Acknowledgements: \\ Authors wish to thank Dr. E.S. Ovchinnikova (University of Sydney, Australia) for assistance in experiments with \\ pea molecular markers. \\ Supported by Russian Science Foundation, grant № 14-24-00135 \\ Received December 14, 2015
}

\section{Abstract}

This article presents a review of current data on genetic mapping of pea (Pisum sativum L.) genes participating in development and regulation of arbuscular-mycorrhizal and legume-Rhizobial symbioses. By means of mutational analysis several regulatory symbiotic genes (Sym-genes) were identified in model and crop legumes, particularly, among them more than 40 pea Sym-genes. Some of them are already cloned and sequenced, and structural and functional similarity was demonstrated for orthologous Sym-genes in different legume species. The functions of these genes are diverse and include the control of perception of the microsymbiont's signal molecules, activation of the signal cascade (which is common for both legume-rhizobial and arbuscular-mycorrhizal symbioses), and consequent transcriptional changes in root cortex. To identify the sequence of mutated pea genes, an approach is used that is based on comparative genetic mapping and search for candidate gene in the genome of closely related legume plant barrel medic (Medicago truncatula Gaertn.). The web site www.phytozome.net (D.M. Goodstein et al., 2012) presents the current state of the barrel medic's genome sequencing in the form of genome browser, which facilitates the search for homologous genes and the sequence analysis of candidate genes. Significant similarity of pea and barrel medic genomes allows development of gene-based molecular markers, comparison of obtained pea genetic map with $M$. truncatula genome, and pea gene cloning after finding mutations with similar phenotypic manifestation. Currently, most of pea Sym-genes are mapped in genome; that resulted in identification of the sequences of 14 symbiotic genes. In particular, authors of the present review were able to sequence the pea genes Sym35 - the homologue of NIN of Lotus japonicus (Regel.) K. Larsen (A.Y. Borisov et al., 2003), Sym37 - the homologue of NFR1 of L. japonicus (V.A. Zhukov et al., 2008), Sym 33 - the homologue of IPD3 of barrel medic (E. Ovchinnikova et al., 2011), Cochleata - the homologue of NOOT of barrel medic (J.M. Couzigou et al., 2012). In recent years, considering the development of modern technologies of Next Generation Sequencing and massive genotyping, an avalanche of data on mapping pea gene-based data is being accumulated. Saturation of pea genetic map with markers, undoubtedly, will facilitate mapping of symbiotic genes and identification of their sequences; this will help to broaden the understanding of how the system of genes, which control interactions with beneficial soil microorganisms, functions in pea.

Keywords: legumes, legume-rhizobial symbiosis, arbuscular mycorrhiza, symbiotic plant genes, genetic mapping, synteny, gene-based molecular markers

Mutualistic interactions with microorganisms are essential for evolution and a successful life strategy of terrestrial plants [1, 2]. Benefits acquired by plants as a result of symbiosis are a facilitated uptake of minerals from soil and the enhanced tolerance to infections and abiotic stressors [3, 4]. Arbuscular mycorrhiza (AM), an interaction between plant roots and Glomeromycota fungi, is the most common endosymbiosis typical of $80-90 \%$ land plants. AM provides 
nutrient assimilation (mainly phosphorus and nitrogen-containing substances) from soil [4]. The symbiosis between legume Fabaceae plants and rhizobia ( $\mathrm{Al}$ phaproteobacteria, Betaproteobacteria and Gammaproteobacteria) is best known among the nitrogen-fixing plant-microbe symbioses. In legume-rhizobium symbiosis (LRS) the specialized structures (nodules) colonized by bacteria that fix atmospheric nitrogen are developed on plant roots [3]. AM and LRS have a lot of similarities, pointing to their evolutionary relationship [5, 6]. High genetic and metabolic integration of the partners is characteristic of both symbioses. AM and LRS development involves certain molecular and cellular events which are clearly interrelated among partners and accompanied by a constant exchange of signals and metabolites [6, 7].

Experimental mutagenesis is widely used to elucidate the mechanisms underlying formation and the functioning of mutualistic plant-microbe symbioses. In particular, extensive collections of bean mutants allow to identify several dozen regulatory symbiotic genes [8-11], also called Sym (symbiosis) genes [12]. Many of them have been cloned and sequenced, and various legume species show the similarities in structure and activity of orthologous Sym genes. The functions of these genes vary and comprise the control of reception of the signaling molecules produced by microsymbionts, activation of common signaling cascade for AM and LRS (CSC) and the subsequent changes in transcriptome of the root cortex cells $[6,7,13]$.

Garden pea (Pisum sativum L.) belongs to the most important legume crop in Russia and in the world [14]. There are over 100 independent pea mutants defective in LRS (rarely AM) development with 44 Sym genes affected [1, $8,9,15-21]$. A promising approach to identification of the sequence of mutated pea genes is based on a comparative genetic mapping and search for candidate gene in the genome of closely related legume plant barrel medic Medicago truncatula Gaertn. and Lotus japonicus (Regel.) K. Larsen [8, 22-24].

The purpose of this paper is to overview current data on the genetic mapping of pea Sym genes, including the results obtained in ARRIAM.

Genetic mapping technique. Genetic mapping is based on the classical genetics including determination of linkage groups and estimation of recombination frequency. The distances between genes are measured in map units (m.u.)/Centimorgan (cM) equal to one percent recombinant phenotypes [25]. Genetic mapping involves statistical analysis of massive data on marker allele segregation in a certain generation after the crossing. To this end, at least a dozen of software has been developed, for example, MAPMAKER 3.0, MapL98, JoinMap 4.1, etc. [26-30].

Both morphological and molecular markers (protein- and DNA-based) allow pea gene mapping, however, only the involvement of DNA markers in genetic analysis made it possible to develop large-scale genetic maps with high resolution [31]. Over the past 25 years, various versions of the pea genome genetic maps have been constructed with the use of molecular markers [22, 32-43].

Gene-specific EST (expressed sequence tag) markers identified by amplification of the expressed sequence fragments are considered the most appropriate for genetic mapping pea genes after their detection by experimental mutagenesis. To design primers, the known EST sequence is commonly used. If the restriction site of the endonuclease applied to detect an allelic state of the amplification product coincides with the single nucleotide polymorphism site, the markers are referred to as CAPS (cleaved amplified polymorphic sequences) type markers. Allelic polymorphism of such markers is manifested as different numbers and sizes of the resulting restriction fragments separated by agarose gel electrophoresis [44]. 
Gene-specific markers in legumes allow to exploit the phenomenon of genomic synteny to transfer knowledge between model (Lotus japonicus, alfalfa) and crop legumes including pea [24, 45]. Synteny is referred to as the same order of homologous genes on the chromosomes of different species. This is micro-synteny in case of synteny within a cluster of several closely located genes, and this is macro-synteny if such a pattern is typical of the whole chromosomes or their extended sections.

Research aimed at developing new gene-specific markers and construction of genetic maps for legumes disclosed both macro- and micro-synteny in their genomes [22, 40]. Detection of high synteny among pea and alfalfa Medicago truncatula genomes generated a new impetus to the pea genetics development, especially after the successful sequencing of the alfalfa genome. Due to high genome similarity, the knowledge about the alfalfa genes can be used in studying pea genes, developing their gene-specific markers and gene cloning, once homologous mutations (i.e., mutations with similar phenotypic manifestation) found [24]. The Plant Comparative Genomics portal of the Department of Energy's Joint Genome Institute (USA, http://www.phytozome.net) [46] represents current information on alfalfa genome sequencing using interface of a genome browser that facilitates the search for homologous genes and candidate gene analysis.

Genetic mapping as a tool for identification of pea symbiotic gene sequences. Over the past 10 years, the set of more than 100 genespecific molecular markers has been designed in ARRIAM for mapping pea Sym-genes of all linkage groups. In this, we used known ESTs which positions in the genome are described in literature (so-called anchor markers).

Oligonucleotide primers for PCR and amplification of target DNA fragments in different pea lines have been designed using nucleotide sequences of selected ESTs from GenBank (NCBI, http://www.ncbi.nlm.nih.gov). The resulting set has been allowed us to define first or clarify the localization of ten symbiotic genes [20, 47, 48]. The figure shows a generalized diagram summarizing all the data, including those obtained in ARRIAM, on the genetic mapping of pea symbiotic genes [9, 20, 47-49].

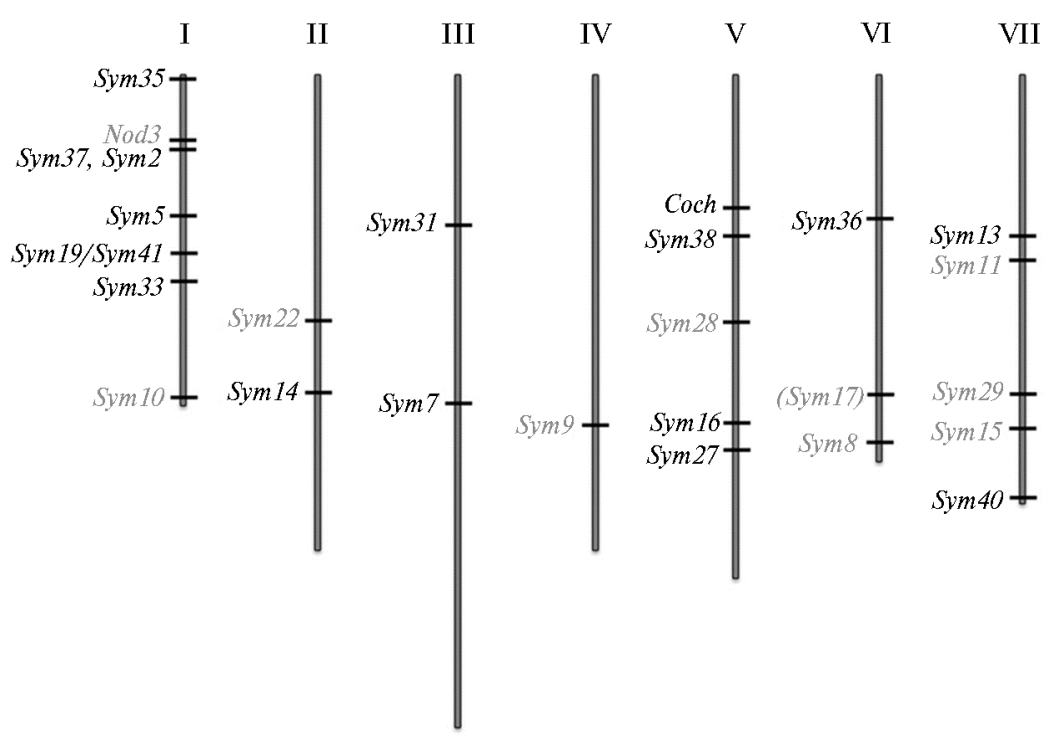

Pea (Pisum sativum L.) symbiotic (Sym) gene mapping: I-VII - the linkage groups. For Sym 17 (in parentheses) the position should be additionally confirmed [50]. The genes which position has been determined or confirmed in ARRIAM (St. Petersburg, Russia) are marked black and those reported 
by other researchers are marked gray. The relative position of these genes is not defined: CochSym38, Sym16-Sym27, Sym14-Sym22, Sym11-Sym13, Sym15-Sym29.

Genetic mapping of mutants using gene-specific markers allowed us to identify positions of 13 Sym-genes in pea. Many of them were determined simultaneously with that of orthologous genes in other legumes, including model species [20, 48, 51-57]. Generalized scheme to determine order of the pea genes included four steps. These are the gene localization on pea genetic map; search for known genes in the syntenic region of the model legumes (Medicago truncatula or Lotus japonicus); selection of candidate homologous genes for the target pea gene by phenotypic comparison between the mutants in pea and the model legume species; amplification and sequencing the pea gene with the primers designed based on the sequence of a model legume candidate gene [8].

The seven pea genes have been sequenced in ARRIAM independently or in collaboration with world's leading laboratories. Of them, the pea Sym33, Sym35 and Sym37 genes have been sequenced based on the homology to alfalfa gene IPD3 [56], Lotus japanese gene NIN [52] and NFR1 gene [54], respectively. The Sym33 gene encodes the protein that interacts with $\mathrm{Ca}^{2+}$-calmodulindependent protein kinase (CaM kinase), the central component of common signaling cascade (CSC), Sym35 gene encodes the LRS-specific CSC-dependent transcription factor, and Sym37 genes encodes the Nod factor (bacterial signal) receptor [6]. The pea Sym40 gene was identified as a homologue of previously known gene $E F D$, encoding a transcription factor of the ethylene response factor (ERF) group in alfalfa [48], and the mutation corresponding gene Sym41 is a variant (weak allele) of another symbiotic pea gene Sym 19, encoding the CSCinvolved receptor kinase [20]. The orthologous genes Cochleata and NOOT controlling nodule meristem have been recently identified as homologs of Arabidopsis thaliana (L.) Heyhn. BOP1 and BOP2 genes involved in leaf and floral morphogenesis [57]. Six of these pea genes have been sequenced based on the gene maps except Sym34 with unknown localization. For Sym34 sequencing the homology to the alfalfa NSP1 gene which encodes CSC-dependent transcription factor common to LRS and AM was assumed solely on the basis of the phenotype of the pea mutant [21].

Thus, in pea the nucleotide sequences of 14 Sym-genes are presently identified which is only a third of that identified by mutational analysis, i.e., many Sym-genes have yet to be mapped and sequenced.

Next generation technologies - an outlook. In recent years, with the development of next-generation sequencing and massive genotyping, the information on gene-specific makers in pea is increasingly accumulated. Next generation sequencing (NGS) allows a high speed to read a great number of fragments, which makes it possible to analyze polymorphism of thousands sequences considered as potential markers. Massive genotyping using GoldenGat microchips (Illumina, USA) allows a one-time analysis of thousands designed markers. Due to these approaches, several thousand gen-specific markers have been mapped in pea in the past two years [43].

The whole genome sequencing in $P$. sativum undoubtedly will facilitate genetic mapping of the symbiotic genes. However, pea, like many other legumes, is still waiting for a chance to be among the species with sequenced genomes [58], while its studies are mostly limited to transcriptome sequencing [59-62].

Thus, the use of gene-specific markers for genetic mapping allows to exploit genome synteny to transfer data obtained for model legumes (Lotus japanese, alfalfa) to economically significant crops, including pea. Design of newtype "interspecies" markers derived from pairs of orthologous genes from different leguminous plants and saturation of pea genetic map obviously can greatly 
assist in the implementation of a complete pea genome assembly based on the next generation sequencing (NGS). In turn, the mapping of symbiotic genes and identification of their sequences will help in better understanding of how the pea genes can control plant interaction with beneficial soil microorganisms.

\section{R E F E R E N C E S}

1. G i a n i n a z z i - P e a r s o n V. Plant cell responses to arbuscular mycorrhizal fungi: getting to the roots of the symbiosis. The Plant Cell, 1996, 8: 1871-1883 (doi: 10.1105/tpc.8.10.1871).

2. Brundrett M.C. Coevolution of roots and mycorrhizas of land plants. New Phytologist, 2002, 154: 275-304 (doi: 10.1046/j.1469-8137.2002.00397.x).

3. D i l w o r th M.J., J a me s E.K., S p re n t J.I., N e w t o n W.I. Nitrogen-fixing leguminous symbioses. Springer Science+Business Media B.V., 2008 (doi: 10.1007/978-1-4020-3548-7).

4. $\quad \mathrm{S} \mathrm{m}$ it h S.E., R e a d D.J. Mycorrhizal symbiosis. Academic Press, NY, USA, 2008.

5. Pa r n is k e M. Arbuscular mycorrhiza: the mother of plant root endosymbioses. Nat. Rev. Microbiol., 2008, 6: 763-775 (doi: 10.1038/nrmicro1987).

6. Old royd G.E. Speak, friend, and enter: signalling systems that promote beneficial symbiotic associations in plants. Nat. Rev. Microbiol., 2013, 11(4): 252-263 (doi: 10.1038/nrmicro2990).

7. Go b b to E. Recent developments in arbuscular mycorrhizal signaling. Curr. Opin. Plant Biol., 2015, 26: 1-7 (doi: 10.1016/j.pbi.2015.05.006).

8. Borisov A.Yu., Shtark O.Yu., Zhukov V.A., Ne mankin T.A., Naumkina T.S., Pinaev A.G., Akhtemova G.A., Voroshilova V.A., Ovchinnikova E.S., Rychagova T.S., Tsyganov V.E., Zhernakov A.I., Kuznetsova E.V., Gri shina O.A., Sulima A.S., Fedorina Ya.V., Chebotar' V.K., Bisseling T., Lemanso F., Dzhianinazzi-Pirson V., Rate P., Sankhuan Kh., Stoug a rd I., B e rg G., Makfi K., E 11 is N., Tik ho novi ch I.A. Sel'skokhozyaistvennaya biologiya [Agricultural Biology], 2011, 3: 41-47. Available http://www.agrobiology.ru/32011 borisov.html. No date (in Russ.).

9. B orisov A.Y., Danilova T.N., Ko roleva T.A., Naumkina T.S., Pavlova Z.B., Pinaev A.G., Shtark O.Y., Tsyganov V.E., Voroshilova V.A., Zhe rnakov A.I., Zhukov V.A., Tikhonovi ch I.A. Pea (Pisum sativum L.) regulatory genes controlling development of nitrogen-fixing nodule and arbuscular mycorrhiza: fundamentals and application. Biologia, 2004, 59(Suppl 13): 137-144.

10. Sandal N., Petersen T.R., Murray J., Umehara Y., Karas B., Yano K., Kumagai H., Yoshikawa M., S a ito K., Hay a shi M., Murakami Y., Wang X., Hakoyama T., Imaizumi-Anraku H., S ato S., Kato T., Che n W., Hossa in M.S., Shibat a S., Wang T.L., Yokota K., Larsen K., Kanamori N., Madsen E., Radutoiu S., Madsen L.H., Radu T.G., Krusell L., Ooki Y., Ba nba M., B etti M., Rispail N., Skøt L., Tuck E., Perry J., Yoshida S., Vickers K., Pike J., Mulder L., Charpentier M., Müller J., Ohtomo R., Kojima T., Ando S., Marquez A.J., Gresshoff P.M., Harada K., Webb J., Hat a S., Suganuma N., Kouchi H., Kaw as aki S., Tabat a S., Hayashi M., Parniske M., Szczyglowski K., Kawaguchi M., Stougaard J. Genetics of symbiosis in Lotus japonicus: recombinant inbred lines, comparative genetic maps, and map position of 35 symbiotic loci. Mol.-Plant Microbe Interact., 2006, 19: 80-91 (doi: 10.1094/MPMI-19-0080).

11. Pislariu C.I., Murray J.D., Wen J., Cosson V., Muni R.R.D., Wang M., Benedito V.A., Andriankaja A., Cheng X., Torres J.I., Mondy S., Zhang S., Taylor M.E., Tad ege M., R a tet P., Mysore K.S., Chen R., Udvardi M.K. A Medicago truncatula tobacco retrotransposon insertion mutant collection with defects in nodule development and symbiotic nitrogen fixation. Plant Physiol., 2012, 159(4): 1686-1699 (doi: 10.1104/pp.112.197061).

12. Li e T.A. Temperature-dependent root-nodule formation in pea cv. Iran. Plant and Soil, 1971, 34: 751-752.

13. Oldroyd G.E., Downie J.A. Coordinating nodule morphogenesis with rhizobial infection in legumes. Annu. Rev. Plant Biol., 2008, 59: 519-546 (doi: 10.1146/annurev.arplant.59.032607.092839).

14. Graham P.H., V a n c C.P. Legumes: importance and constraints to greater use. Plant Physiol., 2003, 131: 872-877 (doi: 10.1104/pp.017004).

15. Gui n e 1 F.C., G e i 1 R.D. A model for the development of the rhizobial and arbuscular mycorrhizal symbioses in legumes and its use to understand the roles of ethylene in the establishment of these two symbioses. Can. J. Bot., 2002, 80: 695-720 (doi: 10.1139/b02-066).

16. Tsyganov V.E., Voroshilova V.A., Priefer U.B., Borisov A.Y., Tikhonovich I.A. Genetic dissection of the initiation of the infection process and nodule tissue development in the Rhizobium-pea (Pisum sativum L.) symbiosis. Ann. Bot., 2002, 89: 357-366 (doi: 10.1093/aob/mcf051).

17. J a cobi L.M., Petrova O.S., Tsyganov V.E., Borisov A.Y., Tikhonovich I.A. 
Effect of mutations in the pea genes Sym33 and Sym40. I. Arbuscular mycorrhiza formation and function. Mycorrhiza, 2003, 13: 3-7 (doi: 10.1007/s00572-002-0188-3).

18. J a cobi L.M., Zubkova L.A., B a rmi cheva E.M., Tsyganov V.E., Bori sov A.Y., Tikhonovich I.A. Effect of mutations in the pea genes Sym33 and Sym40. II. Dynamics of arbuscule development and turnover. Mycorrhiza, 2003, 13: 9-16 (doi: 10.1007/s00572-002-0189-2).

19. Voroshilova V.A., D e m chenko K.N., B rewin N.J., B or is ov A.Y., Tikho$\mathrm{novi} \mathrm{ch}$ I.A. Initiation of a legume nodule with an indeterminate meristem involves proliferating host cells that harbour infection threads. New Phytologist, 2009, 181: 913-923 (doi: 10.1111/j.1469-8137.2008.02723.x).

20. O $\mathrm{v} \mathrm{ch}$ i n $\mathrm{nik}$ v a E. Genetic analysis of symbiosome formation. PhD thesis. Wageningen University, Wageningen, NL, 2012.

21. Shtark O.Y., Sulima A.S., Zhernakov A.I., Kliukova M.S., Fedorina J.V., Pinaev A.G., Kryukov A.A., Akhtemova G.A., Tikhonovich I.A., Zhu k o v V.A. Arbuscular mycorrhiza development in pea (Pisum sativum L.) mutants impaired in five early nodulation genes including putative orthologs of NSP1 and NSP2. Symbiosis, 2016, 68(1): 129-144 (doi: 10.1007/s13199-016-0382-2).

22. Aubert G., Morin J., Jacquin F., Loridon K., Quillet M.C., Petit A., Rameau C., Lejeune-Hénaut I., Huguet T., Bursti n J. Functional mapping in pea, as an aid to the candidate gene selection and for investigating synteny with the model legume Medicago truncatula. Theor. Appl. Genet., 2006, 112(6): 1024-1041 (doi: 10.1007/s00122-005-0205-y).

23. Zhukov V.A., Shtark O.Yu., B orisov A.Yu., Tikhonovich I.A. Genetika, 2009, 45(11): 1449-1460 (in Russ.).

24. Young N.D., Udvardi M. Translating Medicago truncatula genomics to crop legumes. Curr. Opin. Plant Biol., 2009, 12(2): 193-201 (doi: 10.1016/j.pbi.2008.11.005).

25. I nge-Ve chto mov S.G. Genetika s osnovami selektsii [Genetics and basic breeding]. St. Petersburg, 2010 (in Russ.).

26. Lander E.S., Green P., Abrahamson J., B a rlow A., Daly M.J., Linc o $1 \mathrm{n} \mathrm{S.E.,} \mathrm{Newburg}$ L. MAPMAKER, an interactive computer package for constructing primary genetic linkage maps of experimental and natural populations. Genomics, 1987, 1: 174-181 (doi: 10.1016/0888-7543(87)90010-3).

27. U k a i Y. MAPL: a package of computer programs for construction of DNA polymorphism linkage maps and analysis of QTL. Breeding Sci., 1995, 45: 139-142 (doi: 10.1270/jsbbs1951.45.139).

28. Va n O o ije n J.W. Multipoint maximum likelihood mapping in a full-sib family of an outbreeding species. Genet. Res., 2011, 93(5): 343-349 (doi: 10.1017/S0016672311000279).

29. Ch e e m a J., D i c k s J. Computational approaches and software tools for genetic linkage map estimation in plants. Briefing in Bioinformatics, 2009, 10(6): 595-608 (doi: 10.1093/bib/bbp045).

30. Z h e r nak ov A.I. F2Breed. Programma dlya otsenki rekombinatsii mezhdu geneticheskimi lokusami $i$ geneticheskikh markerov $v$ mnogomernom prostranstve pri analize kosegregatsii priznakov $v F_{2}$-populyatsii [Program for evaluating recombination between genetic loci and genetic markers in a multidimensional space to analyze cosegregation of traits in $\mathrm{F}_{2}$-population]. State Reg. Cert. Cert. № 2012619482. Registered October 19, 2012 (in Russ.).

31. Ezhova T.A., Lebedeva O.V., Ogarkova O.A., Pen in A.A., Soldatova O.P., $\mathrm{S}$ h e s t a k o v S.V. Arabidopsis thaliana - model'nyi ob"ekt genetiki rastenii [Arabidopsis thaliana - a model organisms in plant genetics]. Moscow, 2003 (in Russ.).

32. We eden N.F., Swi e cicki W.K., A mbrose M., Timmerman G.M. Linkage groups of pea. Pisum Genetics, 1993, 25: 4.

33. We eden N.F., Swi e c i cki W.K., Tim me rman-Vaughan G.M., Ellis T.H.N., A mbrose M. The current pea linkage map. Pisum Genetics, 1996, 28: 1-4.

34. H a 11 K.J., P a rke r J.S., E 11 is T.H.N., Turner L., Knox M.R., Hofer J.M.I., Lu J., Fer randiz C., Hunter P.J., T a y lor J.D., B a i rd K. The relationship between genetic and cytogenetic maps of pea. II. Physical maps of linkage mapping populations. $G e-$ nome, 1997, 40: 755-769 (doi: 10.1139/g97-798).

35. Flave 11 A.J., Knox M.R., Pe a r c e S.R., E 11 is T.H. Retrotransposon-based insertion polymorphisms (RBIP) for high throughput marker analysis. The Plant Journal, 1998, 16(5): 643-650 (doi: 10.1046/j.1365-313x.1998.00334.x).

36. La u c o u V., Ha u rog n e K., E 11 is N., R a m e a u C. RAPD-based genetic linkage map of Pisum sativum. Theor. Appl. Genet., 1998, 97: 905-915 (doi: 10.1007/s001220050971).

37. We e de n N.F., E 11 is T.H.N., Ti m me rman-Vaughan G.M., S wi e cicki W.K., Roz ov S.M., B e rd nik ov V.A. A consensus linkage map for Pisum sativum. Pisum Genetics, 1998, 30: 1-4.

38. Irzykowska L., Wolk o B., Swi e c i cki W.K. The genetic linkage map of pea (Pisum sativum L.) based on molecular, biochemical and morphological markers. Pisum Genetics, 2001, 33: 13-18.

39. W e e d e $\mathrm{n}$ N.F., M offet M. Identification of genes affecting root mass and root/shoot ratio in a JI1794 x «Slow» RIL population. Pisum Genetics, 2002, 34: 28-31. 
40. Bordat A., S avo is V., Nicolas M., S ls e J., Chauveau A., Bourgeois M., Potier J., Houtin H., Rond C., Murat F., Marget P., Aubert G., Burstin J. Translational genomics in legumes allowed placing in silico 5460 unigenes on the pea functional map and identified candidate genes in Pisum sativum L. G3: Genes, Genomes, Genetics, 2011, 1(2): 93-103 (doi: 10.1534/g3.111.000349).

41. Leonforte A., Sudheesh S., Cogan N.O., Salisbury P.A., Nicolas M.E., Materne M., Forste r J.W., Kau r S. SNP marker discovery, linkage map construction and identification of QTLs for enhanced salinity tolerance in field pea (Pisum sativum L.). BMC Plant Biol., 2013, 13: 161 (doi: 10.1186/1471-2229-13-161).

42. Duarte J., Riviere N., Baranger A., Aubert G., Burstin J., Cornet L., Lavaud C., Lejeune-Henaut I., Martinant J.P., Pichon J.P., Pilet-Naye 1 M.L., B out et G. Transcriptome sequencing for high throughput SNP development and genetic mapping in Pea. Genomics, 2014, 15: 126 (doi: 10.1186/1471-2164-15-126).

43. Sindhu A., Ramsay L., Sanderson L.A., Stonehouse R., Li R., Condie J., Shunmugam A.S.K., Liu Y., Jha A.B., Diapari M., Burstin J., Aubert G., T a r' a $n$ B., B e t t K.E., W a r k e $n$ t i n T.D., S h a r p e A.G. Gene-based SNP discovery and genetic mapping in pea. Theor. Appl. Genet., 2014, 127(10): 2225-2241 (doi: 10.1007/s00122-014-2375-y).

44. Konie c zny A., Ausubel F.M. A procedure for mapping Arabidopsis mutations using codominant ecotype-specific PCR-based markers. The Plant Journal, 1993, 4: 403-410 (doi: 10.1046/j.1365-313X.1993.04020403.x).

45. Zhukov V.A., Kuznetsova E.V., Ovchinnikova E.S., Rychagova T.S., Ti tov V.S., Pina ev A.G., B or is ov A.Y., Moffet M., Domoney C., E 11 is T.H.N., Rate t P., We ede n N.F., Tikhonovich I.A Gene-based markers of pea linkage group V for mapping genes related to symbioses. Pisum Genetics, 2007, 39: 19-25.

46. Goodste in D.M., Shu S., How on R., N e u p a ne R., Hayes R.D., Fazo J., Mitros T., Dirks W., Hellsten U., Putnam N., Rokhsar D.S. Phytozome: a comparative platform for green plant genomics. Nucl. Acids Res., 2012, 40(Database issue): D1178-D1186 (doi: 10.1093/nar/gkr944).

47. Zhukov V.A., Nemankin T.A., Ovchinnikova E.S., Kuznetsova E.V., Zhernakov A.I., Titov V.S., Grishina O.A., Sulima A.S., Borisov Ya.G., B o r i s o v A.Yu., T i k h o n o v i c h I.A. V sbornike: Faktori eksperimental'noï evolyutsii organizmiv [In: The factors of experimental evolution. V. 9]. Kiev, 2010. Tom 9: 30-34 (in Russ.).

48. $\mathrm{N}$ e $\mathrm{m}$ a $\mathrm{n} \mathrm{k} \mathrm{i} \mathrm{n} \mathrm{T.A.} \mathrm{Analiz} \mathrm{geneticheskoi} \mathrm{sistemy} \mathrm{gorokha} \mathrm{(Pisum} \mathrm{sativum} \mathrm{L.),} \mathrm{kontroliruyushchei}$ razvitie arbuskulyarnoi mikorizy $i$ azotfiksiruyushchego simbioza. Avtoreferat kandidatskoi dissertatsii [Analysis of pea (Pisum sativum L.) genetic system which controls the development of arbuscular mycorrhiza and nitrogen-fixing symbiosis. PhD Thesis]. St. Petersburg, 2011 (in Russ.).

49. Titov V.S. Geneticheskoe kartirovanie simbioticheskikh genov gorokha posevnogo (Pisum sativum L.). Kvalifikatsionnaya rabota magistra [Genetic mapping of symbiotic genes in pea (Pisum sativum L.). Master's Thesis]. St. Petersburg, 2012 (in Russ.).

50. Kn e e $n$ B.E., W e e d e n N.F., La R u e T.A. Non-nodulating mutants of Pisum sativum (L.) cv. Sparkle. J. Hered., 1994, 85(2): 129-133.

51. Kruse 11 L., Madsen L.H., S ato S., Aubert G., Genua A., Szczyglowski K., Duc G., Kaneko T., Tabata S., de Bruijn F., Pajuelo E., Sandal N., $\mathrm{S}$ t o u g a a r d J. Shoot control of root development and nodulation is mediated by a receptorlike kinase. Nature, 2002, 420(6914): 422-426 (doi: 10.1038/nature01207).

52. B orisov A.Y., Madsen L.H., Tsyganov V.E., Umehara Y., Voroshilova V.A., Batagov A.O., Sandal N., Mortensen A., Schauser L., E1lis N., Tikhonovich I.A., Stouga ard J. The Sym35 gene required for root nodule development in pea is an ortholog of Nin from Lotus japonicus. Plant Physiol., 2003, 131: 1009-1017 (doi: 10.1104/pp.102.016071).

53. Lévy J., Bres C., Geurts R., Chalhoub B., Kulikova O., Duc G., Journet E.P., Ané J.M., Lauber E., B iss e 1 ing T., Dénarié J., Rosenberg C., $\mathrm{D}$ e b e 11 é F. A putative $\mathrm{Ca}^{2+}$ and calmodulin-dependent protein kinase required for bacterial and fungal symbioses. Science, 2004, 303(5662): 1361-1364 (doi: 10.1126/science.1093038).

54. Zhukov V., Radutoiu S., Madsen L.H., Rychagova T., Ovchinnikova E., B orisov A., Tikhonovich I., Stougaard J. The pea Sym37 receptor kinase gene controls infection-thread initiation and nodule development. Mol. Plant-Microbe Interact., 2008, 21(12): 1600-1608 (doi: 10.1094/MPMI-21-12-1600).

55. Krusell L., Sato N., Fukuhara I., Koch B.E., Grossmann C., Okamoto S., Oka-Kira E., Otsubo Y., Aubert G., Nakagawa T., Sato S., Tabata S., Duc G., Parniske M., Wang T.L., Kawaguchi M., Stouga ard J. The Clavata2 genes of pea and Lotus japonicus affect autoregulation of nodulation. The Plant Journal, 2011, 65(6): 861-871 (doi: 10.1111/j.1365-313X.2010.04474.x).

56. Ovchinnikova E., Journet E.P., Chabaud M., Cosson V., Ratet P., Duc G., Fedorova E., Liu W., Op den Camp R., Zhukov V., Tikhonovich I., Bo- 
risov A., B isseling T., Limpens E. IPD3 controls the formation of nitrogen-fixing symbiosomes in pea and Medicago spp. Mol. Plant-Microbe Interact., 2011, 24(11): 1333-1344 (doi: 10.1094/MPMI-01-11-0013).

57. Couzigou J.M., Zhukov V., Mondy S., Abu el Heba G., Cosson V., E1lis T.H., Ambrose M., Wen J., Tadege M., Tikhonovich I., Mysore K.S., Putterill J., Hofer J., B orisov A.Y., Ratet P. NODULE ROOT and COCHLEATA maintain nodule development and are legume orthologs of Arabidopsis BLADE-ON-PETIOLE genes. The Plant Cell, 2012, 24(11): 4498-4510 (doi: 10.1105/tpc.112.103747).

58. Varshney R.K., Clos e T.J., S ingh N.K., Hois ington D.A., Cook D.R. Orphan legume crops enter the genomics era! Curr. Opin. Plant Biol., 2009, 12(2): 202-210 (doi: 10.1016/j.pbi.2008.12.004).

59. Zhukov V.A., Kulaeva O.A., Zhernakov A.I., Tikhonovich I.A. «Next Generation Sequencing» for studying transcriptome profiles of tissues and organs of garden pea (Pisum sativum L.) (review). Agricultural Biology, 2015, 50(3): 278-287 (doi: 10.15389/agrobiology.2015.3.278eng) (in Engl.).

60. Sudheesh S., Sawbridge T.I., Cogan N.O., Kennedy P., Forster J.W., $\mathrm{K}$ a u r S. De novo assembly and characterisation of the field pea transcriptome using RNASeq. BMC Genomics, 2015, 16: 611 (doi: 10.1186/s12864-015-1815-7).

61. Alves-Carvalho S., Aubert G., C a rrère S., Cruaud C., B rochot A.L., J a cquin F., Kle in A., Martin C., B oucherot K., Kreplak J., da Silva C., Moreau S., Ga mas P., Wincker P., Gouzy J., Burstin J. Full-length de novo assembly of RNA-seq data in pea (Pisum sativum L.) provides a gene expression atlas and gives insights into root nodulation in this species. The Plant Journal, 2015, 84(1): 1-19 (doi: $10.1111 /$ tpj. 12967).

62. Zhukov V.A., Zhernakov A.I., Kulaeva O.A., Ershov N.I., Borisov A.Y., Tik ho novich I.A. De novo assembly of the pea (Pisum sativum L.) nodule transcriptome. International Journal of Genomics, 2015, article 695947 (doi: 10.1155/2015/695947). 